\title{
Number and distribution of Barnacle Goose Branta leucopsis colonies on the Timansky coast of the Barents Sea in 2009
}

\author{
Dmitry Dorofeev ${ }^{1}$, Yury Anisimov², Olga Anisimova ${ }^{3} \&$ Konstantin Litvin $^{4}$
}

\author{
${ }^{1}$ Russian Institute for Nature Protection ARRINP, Znamenskoye-Sadki, 117628 Moscow, Russia; \\ e-mail: dmitrdorofeev@gmail.com \\ ${ }^{2}$ Tankhoi, Krasnogvardeiskaya, 34 Baikalsky Biosphere Reserve Reserve, 671220 Republic of Buriatiya, Kabansky region, \\ Russia; e-mail: janisimov@gmail.com \\ ${ }^{3}$ Wetlands International Russia, str. Pobedu, hous 47/5, Korolev city, 141073 Moscow oblast, Russia; \\ e-mail: oyanisimova@gmail.com \\ ${ }^{4}$ Russian Bird Ringing Centre, Leninsky prospect 33, 119071 Moscow, Russia; \\ e-mail: kelitvin@gmail.com
}

\begin{abstract}
During the summer of 2009 we conducted a survey of the coastal zone of the Barents Sea (approx. $330 \mathrm{~km}$ ) between the Velt River and Peschanka-To Lake. The work was aimed at mapping Barnacle Goose Branta leucopsis colonies. We succeeded in describing 12 colonies, containing a total of 4650 Barnacle Goose nests. Some of these colonies are known since the middle of the 1990s, although most were described for the first time. We found the nests predominantly on the lower marshes or sandy islands. Using the inventory in combination with data from satellite images, we estimated the number of breeding pairs along the stretch of coast between Cape Kanin and the Velt river mouth. We suspected that there are not more than 800-1000 pairs of Barnacle Geese along this stretch of coast. This brings the estimate for the total number of breeding pairs from Cape Kanin to Russkiy Zavorot in 2009 to at about 5500-6000 pairs.
\end{abstract}

Key words: Barnacle Goose, new colonies, breeding, Barents Sea coast, salt marshes

\section{INTRODUCTION}

From the beginning of the 1980s, Barnacle Geese started nesting in new habitats: maritime low sandy islands and marshes (Ganter et al. 1999; Pokrovskaya \& Gavrilo 1998). In particular, the salt marshes between the Kanin Peninsula and Vaigach Island provide suitable nesting habitats. However, knowledge about the density and exact distribution of the nesting colonies is incomplete. Mineev \& Mineev (2009) found colonies in the lower part of the Velt River (30-50 nests), on the mainland part of the Sengeisky Strait (250 nests), at the mouth of Kolokolkova Bay (3500 nests) and on the islands on the NW part of the Peschanka-To Lake (150 breeding pairs).

\section{METHODS}

During summer 2009, we counted the Barnacle Goose colonies in the coastal zone of the Barents Sea between Velt River mouth and Peschanka-To Lake. In this area, the first Barnacle Goose colony was established on sandy islands and low marshes (Syroechkovsky, 1995). Geese may nest in tundra-like habitats as well but these colonies have a low breeding success presumably because of high predation pressure. The main predators for Barnacle Geese in this region are arctic fox Alopex lagopus and large gulls (Heuglin's Gull Larus heuglini and Glaucous Gull Larus hyperboreus). Prior to fieldwork, we checked satellite images and selected large sandy islands and coastal marshes that seemed potential sites for Barnacle Goose colonies.

We used two inflatable catamarans with outboard motors to reach the survey area. One team worked in Kolokolkova Bay and another sailed along the coast. In the colonies detected, the geographical positions of the nests were recorded using a GPS device. Clutch size was noted for all nests visited. When goslings had hatched, we checked the nests to assessed breeding success. If we found shell membranes in the nest, we assumed that the nest had been successful.

\section{RESULTS AND DISCUSSION}

\section{Peschanka-To}

In the area of the Peschanka-To Lake we found Barnacle Goose colonies on the Yabteingo Islands $\left(68.777^{\circ} \mathrm{N}\right.$ 


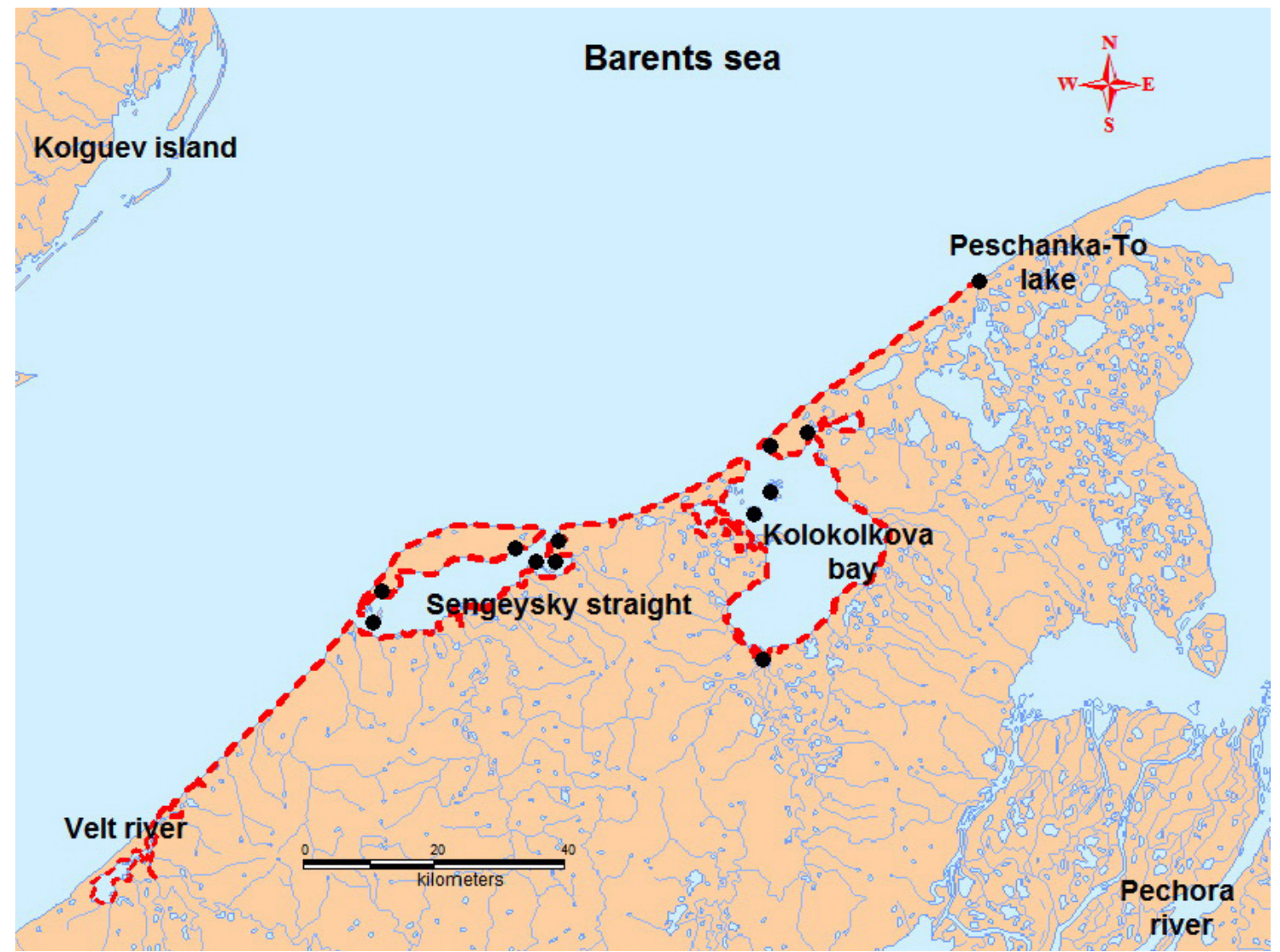

Figure 1. Map of the study area with the surveyed coastline indicated by a dashed line. Black dots show breeding colonies of Barnacle Geese.

$\left.53.074^{\circ} \mathrm{E}\right)$. On these two sandy islands, visited on 1 July, Barnacle Geese nested in mixed colonies with large gulls. We found 195 Barnacle Goose nests, 12 Glaucous Gull nests and 71 Heuglin's Gull nests. This colony may have increased in size at a later date as we found a considerable number of nests $(10.2 \%)$ that contained only one egg. It seemed therefore that egglaying was not yet complete.

\section{Kolokolkova Bay}

In the Kolokolkova Bay fieldwork was carried out during the whole field season (from the beginning of June until the middle of August). In the largest colony near the abandoned village of Tobseda $\left(68.583^{\circ} \mathrm{N}\right.$, $52.341^{\circ} \mathrm{E}$ ) we observed birds from the beginning of nesting through to the middle of August. The spring in 2009 was very late with egg-laying not commencing until around 6-9 June. Normally, geese start to lay eggs in the last days of May. The Tobseda colony is the largest and best known of the newly established colonies in the region. We recorded 1434 Barnacle Goose nests, widely dispersed on sandy dunes, on low and high marshes and in tundra-like habitats. Locally, geese nested in mixed colonies with gulls (mainly on sandy spits).
Another colony was situated at the mouth of Kambalnitza River $\left(68.600^{\circ} \mathrm{N}, 52.458^{\circ} \mathrm{E}\right)$. Here we found about 20 Barnacle Goose nests on low marshes. There may have been more nests at the beginning of the nesting season. On this part of the Kolokolkova Bay coast we frequently noticed Arctic Foxes. In addition, we know that at this colony the local Nenets people collect eggs.

Other Barnacle Goose colonies in the Kolokolkova Bay are situated on the Chaichy Islands $\left(68.533^{\circ} \mathrm{N}\right.$, $\left.52.206^{\circ} \mathrm{E}\right)$ with 797 nests, and at Radiola Island $\left(68.532^{\circ} \mathrm{N}, 52.206^{\circ} \mathrm{E}\right)$ with 206 nests. These islands are low and sandy with small patches of low marshes. Barnacle Geese nest together with large gulls. In the southern part of the Kolokolkova Bay, on the island in the delta of the Neruta River $\left(68.310^{\circ} \mathrm{N}, 52.280^{\circ} \mathrm{E}\right)$, we counted 536 Barnacle Goose nests and several large gull nests.

In total, we found 2952 Barnacle Goose nests in the Kolokolkova Bay area. Comparing our assessment with data collected in previous years it seems that the number of nests in the Kolokolkova Bay has stabilised (see Karagicheva et al. 2011). We suspect that at present geese use all potentially available nesting habitats. A further increase in the number of breeding pairs is therefore not predicted. 


\section{Sengeysky Strait}

In the Sengeysky Strait area we found six Barnacle Goose colonies. One of these colonies had been found in an previous season (Mineev \& Mineev 2005), whereas the other colonies were apparently new. The largest colony was situated close to the abandoned village of Nizny Shar on the north-east coast of the strait $\left(68.464^{\circ} \mathrm{N}, 51.533^{\circ} \mathrm{E}\right)$. In this colony, we recorded 1096 Barnacle Goose nests and more than 100 nests of Heuglin's and Glaucous Gulls. On the small sandy islands to the west and south-west $\left(68.437^{\circ} \mathrm{N}, 51.499^{\circ}\right.$ E) from this colony we found another 2 colonies of Barnacle Geese. One colony consisted of 14 pairs of Barnacle Geese and 80 pairs of gulls. Another colony contained only 4 Barnacle Goose nests and more than 110 pairs of gulls. We suppose that the colonies were recently established, which was supported by the small size of the colonies. We expect therefore that in the years to come the colonies in this particular area will show further growth.

In the eastern part of the Sengeysky Island (68.460 $\mathrm{N}, 51.428^{\circ} \mathrm{E}$ ) we found a colony of Barnacle Geese on the high marshes. This was the only colony without any nests of big gulls. Of 52 nests examined, 23 had been predated. The high predation rate may have been due to Arctic Fox, of which we found footprints. On the southwest part of Sengeysky Island, on the low marshes on the coast of the strait close to Kovriga Hill, we found a second colony $\left(68.400^{\circ} \mathrm{N}, 50.947^{\circ} \mathrm{E}\right)$ with 200 nests. We found this colony in the beginning of August, at the end of the nesting period. Given the late date, we may have missed some nests.

A colony on the two low sandy islands near the abandoned village Verhniy Shar $\left(68.351^{\circ} \mathrm{N}, 50.862^{\circ}\right.$ E; as earlier described by Mineev 2005) was comprised of 135 Barnacle Goose nests and more than 100 nests of large gulls.

In total, we found about 1500 Barnacle Goose nests on the coasts of the Sengeysky Strait. We did not find any colonies on the islands in the lower part of the Velt River, although we observed several Barnacle Goose broods, which may have hatched locally.

\section{West from survey area}

Based on satellite images there appears to be only a small area of suitable breeding habitat between the eastern coast of Kanin Peninsula and the Russkiy Zavorot cape. Moreover, some of the available area may not be used for breeding by Barnacle Goose nesting as the risk for predation by Arctic Fox is large. This is a possible explanation as to why not all areas with low marshes and low sandy places are used for breeding. As a rough estimate, we suggest that on the part of the coastal zone from the Kanin Peninsula to the Velt River there is space for not more than 800-1000 pairs of Barnacle Goose.

\section{Grand total}

In total, about 4650 pairs of Barnacle Geese nested along the surveyed part of the Barents Sea. Considering the total coastal zone from the Kanin Peninsula to Russkiy Zavorot, we estimate a total of 5500-6000 nesting pairs of Barnacle Geese. Future surveys will reveal whether the number of breeding Barnacle Goose in this region will show further growth.

Acknowledgements. The survey was conducted under the financial support of the KNIPP MATRA Small Grants of the Netherlands Embassy and WWF-Russia Arctic programme. Dmitry Dobrynin helped with the satellite images. Paul Shimmings and Jouke Prop made valuable comments on an earlier draft of this manuscript.

\section{REFERENCES}

Ganter, B., Larsson, K., Syroechkovsky, E.V., Litvin, K.E., Leito, A. \& Madsen, J. 1999. Barnacle Goose Branta leucopsis: Russia/Baltic. In: Madsen, J., Cracknell, G. \& Fox, A.D. (eds.). Goose populations of the Western Palearctic. A review of status and distribution. Wetlands International, Wageningen, The Netherlands. National Environmental Research Institute, Ronde, Denmark: 270-283.

Karagicheva, J., Rakhimberdiev, E., Dobrynin, D., Saveliev, A., Rozenfeld, S., Pokrovskaya, O., Stahl, J., Prop, J. \& Litvin, K. 2011. Individual inter-annual nest-site relocation behaviour drives dynamics of a recently established Barnacle Goose Branta leucopsis colony in sub-arctic Russia. Ibis 153: 622-626.

Pokrovskaya, I.V. \& Gavrilo, M.V. 1998. Current distribution of the barnacle goose in Russia. Material for the Red Data Book. Moscow (In Russian)

Mineev, J.N. \& Mineev, O.J. 2009. Birds of the Malozemelskaya tundra and Pechora delta. Nauka, SaintPetersburg. (In Russian)

Mineev, O.J. 2005. Waterfowl of the Malozemelskaya tundra and Pechora river delta. UrO RAN, Ekaterinburg. (In Russian)

Syroechkovsky, E.E. Jr. 1995. News about the nest distribution of the barnacle goose in Russia. Geese Study Group Bulletin of Eastern Europe and Northern Asia No. 1, pp 39-46. (In Russian)

Received 25 July 2012. Accepted 14 June 2013 Guest editor: Paul Shimmings 